DOI https://doi.org/10.30525/978-9934-26-113-8-39

\title{
ФОРМУВАННЯ ПРИРОДНИЧО-НАУКОВОЇ КОМПЕТЕНЦЇ̈ У ЗДОБУВАЧІВ ВИЩОЇ МЕДИЧНОЇ ОСВІТИ
}

\author{
Погоріла I. O. \\ кандидат педагогічних наук, доцент, \\ доиент кафедри біології \\ Національний медичний університет імені О. О. Богомольия \\ Романенко О. В. \\ доктор біологічних наук, професор, \\ завідувач кафедри біологіi \\ Наиіональний медичний університет імені О. О. Богомольия \\ м. Київ, Украӥна
}

Важливим елементом підготовки студентів, які вступили до закладу вищої медичної освіти, є їх залучення до дослідницької діяльності. При цьому необхідно звернути увагу, що чинним Законом України «Про вищу освіту» передбачене оволодіння здобувачами бакалаврського рівня вищої освіти здатності до розв'язування складних спеціалізованих задач у певній галузі професійної діяльності, магістерського рівня до розв'язування задач дослідницького, інноваційного характеру у ній, а освітньо-наукового - до розв'язування комплексних проблем в галузі професійної, дослідницько-інноваційної діяльності [1]. Причому, останній рівень передбачає набуття майбутнім фахівцем теоретичних знань, умінь, навичок та інших компетентностей, достатніх для генерації нових ідей, розв'язання комплексних проблем у галузі професійної й дослідницько-інноваційної діяльності, оволодіння методологією наукової діяльності, проведення наукового дослідження, результати якого мають наукову новизну, теоретичне та практичне значення. Виходячи 3 наведеного вище, починати залучати здобувачів вищої освіти, зокрема медичної, до дослідницької діяльності доцільно як раніше, вже 3 першого року навчання. Адже саме студентський вік $\epsilon$ сприятливим для формування в особистості світоглядних і професійних рис, творчої ініціативи, що мають знайти свого розвитку в подальшій професійній діяльності майбутнього фахівця.

У зв'язку 3 цим важливим завданням науково-педагогічних працівників кафедри біології Національного медичного університету імені О.О. Богомольця $\epsilon$ залучення студентів до дослідницької роботи, мотивування їх до наукових пошуків, ознайомлення їх 3 методами 
наукових досліджень та пов'язаними 3 цим питаннями біоетики, підготовка їх до участі в студентських наукових конференціях, форумах, конкурсах студентських наукових робіт. Виявлення обдарованої молоді, сприяння ii самореалізації має на меті оптимізацію умов підготовки конкурентноспроможних фахівців у галузях медицини та фармації.

3 елементами дослідницької діяльності студенти починають знайомитися в перший рік навчання у закладі вищої медичної освіти, оволодіваючи біологічними основами життедіяльності людини в ході навчальних занять на кафедрі біології Національного медичного університету імені О.О. Богомольця. Це відбувається, зокрема, під час практичних занять з «Медичної біології», яку вивчають майбутні фахівці в галузі охорони здоров'я, і з «Біології з основами генетики» - в галузі фармації. На реалізацію творчого потенціалу особистості націлена й робота студентського наукового гуртка кафедри біології. Залучення до нього студентів, сприяє поглибленому вивченню ними у позааудиторний час названих напрямків науки про життя, активізації в них пізнавального інтересу. Долучитися до такої діяльності мають можливість студенти будь-якого факультету, починаючи вже 3 першого року навчання в закладі вищої медичної освіти. На засіданнях студентського наукового гуртка кафедри біології акцентується увага на сучасних медикобіологічних проблемах. Під час творчих звітів студентів-гуртківців за відповідною тематикою студенти-старшокурсники передають свій досвід гуртківцям-початківцям. Спільно аналізуються труднощі, що можуть виникати в процесі пошукової діяльності за темою дослідження та оформлення його результатів, вирішуються проблемні аспекти в організації роботи студентів-гуртківців. Останні поступово набувають природничонаукової компетенції, здатності використовувати набуті грунтовні знання і вміння у майбутній фаховій діяльності. Діяльність студентського наукового гуртка відбувається з дотриманням принципів добровільності, науковості, системності, академічної доброчесності. В результаті суб'єкт-суб'єктної взаємодії досвідчених викладачів і студентів-гуртківців в останніх активізується оволодіння навичками систематизувати, аналізувати та узагальнювати наукову інформацію, визначати мету дослідження, формулювати гіпотезу, складати план дослідження, здійснювати аналіз отриманих даних, формулювати висновки, а також висловлювати власну точку зору на проблему, що підлягає вивченню, виявляти власний особистісно-ціннісний потенціал, творче мислення, рефлексію.

Саме в студентські роки в особистості розвиваються лідерські якості, соціальна активність, комунікативні здібності, розширюється світогляд, розвиваються прагнення до самоосвіти, самовиховання, самовдоско- 
налення, навчання протягом усього життя [2]. Цьому сприяє участь молоді в роботі студентського наукового гуртка.

\title{
Література:
}

1. Закон України «Про вищу освіту» 2014 (Верховна Рада України). Офіційний сайт Верховної Ради України. <https://zakon.rada.gov.ua/laws/ show/1556-18\#Text> (дата звернення:16 червня 2021 року).

2. Педагогіка та психологія вищої школи: навчальний посібник / Л.Г. Кайдалова, І.С. Сабатовська-Фролкіна, Н.В. Альохіна, Н.В. Шварп. Х.: НФаУ, 2019. - 248 c.

DOI https://doi.org/10.30525/978-9934-26-113-8-40

\section{MORPHOLOGICAL STUDY OF MASTICATORY MUSCLE FIBERS IN HYPOTHYROIDISM}

\author{
Sahan N. T. \\ Candidate of Medical Sciences, \\ Acting Associate Professor at the Department of Pathophysiology \\ Ivano-Frankivsk National Medical University \\ Antymys 0. V. \\ Candidate of Medical Sciences, \\ Associate Professor at the Department of Human Anatomy \\ Ivano-Frankivsk National Medical University \\ Oliynyk R. P. \\ Candidate of Medical Sciences, \\ Assistant Professor at the Dentistry Postgraduate Education \\ Ivano-Frankivsk National Medical University \\ Melnyk Ya. I. \\ 4th year medical student \\ Ivano-Frankivsk National Medical University \\ Ivano-Frankivsk, Ukraine
}

The study of masticatory muscle morphology has been conducted for a long time by many domestic and foreign scientists $[2,4]$. However, there is no clear and unanimous view on the morphology of this muscle in the 